\title{
Jaguar in the Tepalcatepec basin in central-western Michoacán, México
}

\author{
Juan F. Charre-Medellín ${ }^{1 *}$, Esteban Barragán-López ${ }^{2}$, Rogelia Torres-Villa ${ }^{3}$, María del Socorro Alvarado ${ }^{4}$,
} Tiberio C. Monterrubio-Rico ${ }^{1}$, and AleXsandre Gutiérrez-Barragán ${ }^{5}$

${ }^{1}$ Laboratorio de Vertebrados Terrestres Prioritarios, Facultad de Biología, Universidad Michoacana de San Nicolás de Hidalgo, Edificio R. Planta baja, Ciudad Universitaria, Av. Francisco J. Mújica s/n, CP. 58194, Morelia. Michoacán, México. Email: jfcharre@ yahoo.com.mx (JFCM), tmonter2002@yahoo.com.mx (TCMR).

${ }^{2}$ El Colegio de Michoacán, Martínez de Navarrete 505, CP. 59699, Zamora. Michoacán, México. estebar@hotmail.com (EBL).

${ }^{3}$ Unidad Académica de Estudios Regionales, Coordinación de Humanidades, Universidad Nacional Autónoma de México, Avenida Lázaro Cárdenas s/n, , CP. 59510, Zamora. Michoacán, México. Email: rogeliat@hotmail.com (RTV).

${ }^{4}$ Consejo Nacional de Ciencia y Tecnología (CONACyT) - El Colegio de Michoacán, Martínez de Navarrete 505, CP. 59699, Morelia. Michoacán, México. Email: mdsalvarado@conacyt.mx (MSA).

${ }^{5}$ Licenciatura en Biología, Departamento de Investigaciones Científicas y Tecnológicas, Universidad de Sonora. Luis Donaldo Colosio S/N, Colonia Centro, CP. 83000, Hermosillo. Sonora, México. Email: alexsandre190195@gmail.com (AGB).

* Corresponding author

The international conservation status of the jaguar (Panthera onca) is Near Threatened, reason to seek priority regions for its conservation. Both national and international geographical distribution models assume that in the Mexican Pacific slope, the jaguar is present from Sonora to Chiapas and constitute a single subpopulation. However, the possible connectivity routes between different distributional areas in the Pacific region of México, are still unknown. In August 2015, it was initiated a community participatory monitoring program in the southwest of the municipality of Tocumbo, Michoacán, in the Tepalcatepec basin. Exploratory sampling consisted of the opportunistic placement of five Cuddeback $\mathrm{X}$-Change camera traps on tracks and roads where inhabitants of the area had identified wildlife activity. The cameras were placed at a distance of between 200 and 1,000 m. With a sampling effort of 1,200 days/camera, on January 5th, 2017 three photographs of a jaguar were obtained at 00:52 $\mathrm{h}$. The record site is a dirt trail located $3.5 \mathrm{~km}$ from the state limit with Jalisco, on the edges of an agricultural area surrounded by tropical dry deciduous forest at an elevation of 1,287 masl. In addition, potential prey such as white-tailed deer (Odocoileus virginianus), collared peccary (Dicotyles angulatus), coati (Nasua narica), and predators competitors such as puma (Puma concolor) and coyote (Canis latrans) were recorded. The jaguar presence in the Tepalcatepec river basin provides valuable baseline information in two aspects. It incorporates an alternative and suitable route with validating a contact area between Jalisco and Michoacán for the mobility of jaguars. In addition, is supporting evidence for the hypothesis that the state contain key regions for the design of a viable conservation corridor on the central Pacific for the jaguar. Knowing in which areas the jaguars maintain activity facilitates the design of more accurate distribution models and potential corridors for Michoacán and neighboring states. Therefore, survey efforts should continue in these regions, where flora and fauna assemblages include several endangered species.

El estado de conservación del jaguar (Panthera onca) a nivel internacional es casi amenazado, razón por la cual es importante identificar regiones prioritarias para su conservación. Los modelos de distribución geográfica a nivel nacional e internacional suponen que en la vertiente del Pacífico Mexicano, el jaguar está presente desde Sonora a Chiapas y constituye una sola subpoblación. Sin embargo, aún se desconocen las posibles rutas de conectividad entre las diferentes áreas de distribución en la región del Pacífico de México. En agosto de 2015 se inició un programa de monitoreo participativo comunitario en el suroeste del municipio de Tocumbo, Michoacán, en la cuenca de Tepalcatepec. El muestreo exploratorio consistió en la colocación oportunista de cinco trampas de cámara Cuddeback X Change en veredas y caminos donde los habitantes del área habían identificado actividad de vida silvestre. Las cámaras se colocaron a una distancia de entre 200 y 1,000 m. Con un esfuerzo de muestreo de 1,200 días/cámara, el 5 de enero de 2017 se obtuvieron tres fotografías de un jaguar a las 00:52 h. El sitio de registro es un camino de tierra ubicado a $3.5 \mathrm{~km}$ del límite estatal con Jalisco, en los bordes de un área agrícola rodeada de bosque tropical caducifolio a una elevación de 1,287 msnm. Además, se registraron posibles presas como venado de cola blanca (Odocoileus virginianus), pecarí de collar (Dicotyles angulatus), coatí (Nasua narica) y depredadores competidores como el puma (Puma concolor) y el coyote (Canis latrans). La presencia de jaguar en la cuenca del río Tepalcatepec proporciona información valiosa de referencia en dos aspectos. Por un lado, incorpora una ruta alternativa y adecuada para validar un área de contacto entre Jalisco y Michoacán para la movilidad de los jaguares. Además, se refuerza la hipótesis de que el estado de Michoacán presenta regiones importantes para el establecimiento de un corredor biológico viable en el Pacífico central para la conservación del jaguar. Saber en qué áreas mantienen su actividad los jaguares facilita el diseño de modelos de distribución más precisos y corredores potenciales para Michoacán y los estados vecinos. Por lo tanto, los esfuerzos de muestreo deben continuar en estas regiones, donde los ensambles de flora y fauna incluyen varias especies en peligro de extinción.

Key words: camera trap; community monitoring; connectivity; Felidae.

๑c 2018 Asociación Mexicana de Mastozoología, www.mastozoologiamexicana.org

\section{Introduction}

In México, the conservation status of the jaguar (Panthera onca) is Endangered and internationally it is Near Threatened, mainly due to the reduction and fragmentation of its habitat in addition to the fact that it is hunted in retaliation for predation of cattle (Caso et al. 2008; SEMARNAT 2010; Ceballos et al. 2016). In recent years, a consensus among specialists is that long term conservation of jaguar will depend on maintaining a network of suitable habitat corridors allowing the dispersion of individuals among areas 
that present abundant populations (Rabinowitz and Zeller 2010; Rodríguez-Soto et al. 2011; Ceballos et al.2016). Most distributional models designed for México consider that the species occurs into three main geographic areas; the Sierra de Tamaulipas, the Pacific, and the Gulf of México (De la Torre et al. 2018). The Mexican Pacific may be considered the most important in the northern hemisphere, as the jaguar is assumed to persist along the Pacific slope, from Sonora to Chiapas as one large sub-population. However, present considerable vulnerability due to fragmentation, a low protected area availability, population reduction and consequent isolation in the central western states like Michoacán and Colima (De la Torre et al. 2018).

At national level, the central western states (Nayarit, Jalisco, Colima, Michoacán) have been identified as a single high priority area for jaguar conservation due to habitat availability and the possible existence of ongoing connectivity routes (CONANP 2009; Núñez 2011). For the Michoacán state, a small but resident jaguar population has been confirmed in recent years for the Sierra Madre del Sur and for the lower Balsas River Basin (Charre-Medellín et al. 2013; Charre-Medellín et al. 2014b).

The location of the areas with actual jaguar presence, habitat availability and the potential distribution models allowed us to hypothesize the most likely contact areas among neighboring states. To the southeast the contact area with the State of México and Guerrero through the Alto Balsas region. Explained by the proximity and location of the records from the Zicuirán-Infiernillo area (Figure 1; (Charre-Medellín et al. 2014b). However, the contact areas between Michoacán and the northern populations (ColimaJalisco) remained unknown. Most published hypothesis considered as the most likely area of contact, somewhere along the coastal areas and/or mountain ranges in the bor-

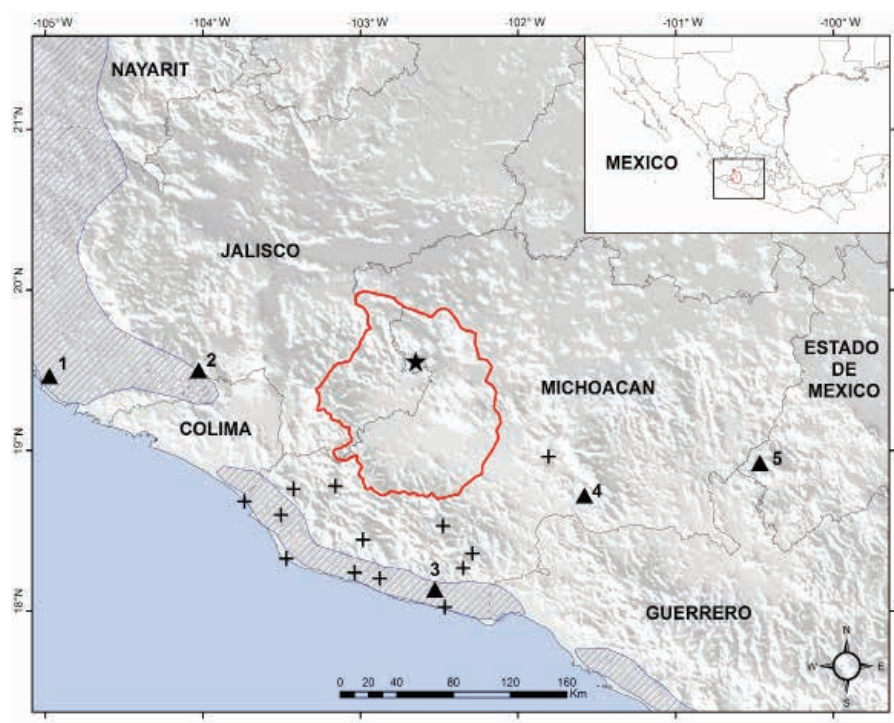

Figure 1. Location of the records of jaguar (Panthera onca) in the Tepalcatepec basin. Current records obtained by camera traps in western México: 1 Cuixmala- Chamela, Jalisco (Núñez 2007). 2) Manantlán, Jalisco (Núñez 2007). 3) Arteaga, Michoacán (Charre-Medellín et al. 2013). 4) Huetamo, Michoacán (Charre-Medellín et al. 2014b). 5) Nanchititla, State of México (Monroy-Vilchos et al. 2008). The star is the new photographic record. Triangles are historical photographic records. The crosses are historical anecdotal records. Red polygon Tepalcatepec Basin. Gray polygon is IUCN distribution of jaguar. der between Michoacán, and Colima-Jalisco (Núñez 2011; Ceballos et al. 2016). However, a total absence of records from coastal areas near Colima state, and from Colima state during the last 50 years (Núñez 2007; Ceballos et al. 2016), rejected the hypothesis of the existence of a contact area somewhere along the lowlands and coastlines on the Michoacán-Colima border (Municipalities of Coahuayana and Tecoman respectively). In the absence of evidence, the International Union for Conservation of Nature (IUCN) outlined a potential distributional map showing a gap in the continuity of their distribution (Figure 1). Therefore, until 2016 it was not possible to determine the contact areas between central and northern Pacific jaguar populations, particularly between Michoacán and Jalisco states.

In the absence of robust information confirming a specific contact area, the generation of alternate hypothesis initiated. One region was considered as promising, the JalMich Sierra (a bordering mountain range shared by Michoacán and Jalisco state). The region included tropical forest remnants along inaccessible canyons and ravines with the confirmed presence of other endangered species. The area corresponds to the geographic region known as the Tepalcatepec river basin.

Previously, this region was not considered as a potential site for jaguar presence. Neither as a part of a potential corridor, since it is located outside most recognized distributional areas for the species in México (Caso et al. 2008; Núñez 2012; Ceballos et al. 2016). The only academic analysis considering its potentiality came from Charre-Medellín et al. (2014a), suggesting the need to survey such region.

\section{Materials and Methods}

Conservation initiatives in the Jalmich mountain range initiated in August 2015. Activities included wildlife surveys by a "Community participatory monitoring program". The activities included the inhabitants of El Palo Bobo, Los Desmontes, El Rodeo and El Santuario localities, in the southwest corner of the municipality of Tocumbo, Michoacán. The area is part of the Jal-mich mountain range, the Cotija cheese region of origin. The regional pride achieved by the international recognition of the cheese brand motivated collective efforts to preserve not only the cheese producing tradition, but also their wildlife heritage, in a "holistic point of view" that included the preservation of cultural and natural heritage (Barragán et al. 2007).

Wildlife monitoring by local communities provides the opportunities to gain information by including all their experience in natural resource management (Botello et al. 2011). The survey sites in Tocumbo municipalities are located in the northwest portion of the state of Michoacán $19^{\circ} 32^{\prime} 45.03^{\prime \prime} \mathrm{N},-102^{\circ} 40^{\prime} 56.26^{\prime \prime} \mathrm{W}$. The area limits with the state of Jalisco and constitute the core of the Tepalcatepec river basin (Figure 1). The entire basin has an approximate area of $17,000 \mathrm{~km}^{2}$ and is characterized by the presence of warm tropical climates, and a rugged terrain with a broad 
altitudinal range of 160 to $3,840 \mathrm{~m}$ (Mendoza et al. 2009). Approximately $41 \%$ of the basin area is dedicated to agriculture, $32 \%$ constitute lowland deciduous forest, and $27 \%$ is temperate forests (INEGI 2010).

Exploratory sampling (without a balanced design), consisted of the opportunistic placement of five Cuddeback $\mathrm{X}$-Change camera traps along trail and dirt roads where footprints reveled intense wildlife activity. The cameras were programmed with a one-minute delay and to obtain three consecutive photographs each triggering event. The cameras were placed at distances between 200 and 1,000 $m$ at a random pattern.

\section{Results}

With a sampling cumulative effort of 1,200 days/camera, three photographs of a jaguar (Panthera onca) were obtained at 00:52 h, on January 5th, 2017. The record site is a dirt trail located $3.5 \mathrm{~km}$ from the state limit with Jalisco, on the edges of an agricultural area surrounded by tropical dry deciduous forest at an elevation of 1,287 masl (Figure 2). The location of the record is $144 \mathrm{~km}$ of from the nearest jaguar populations in the Manantlán Reserve in a mountain range. However, is $244 \mathrm{~km}$ from the coastal population located in Cuixmala-Chamela, both areas in Jalisco state (Núñez 2007). On the interior of Michoacán to the south, the nearest population is located at $156 \mathrm{~km}$ in the Arteaga municipality on the Sierra Madre del Sur, and 164 $\mathrm{km}$ from the records in Huetamo municipality on the lower Balsas basin near the Zicuiran Infiernillo Biosphere Reserve (Charre-Medellín et al. 2013; Charre-Medellín et al. 2014b). The record is located at $240 \mathrm{~km}$ from the jaguar record obtained in Nanchititla, State of México (Monroy-Vilchis et al. 2008); Figure 1). In addition to the jaguar, the species assemblages included prey species as the white-tailed deer (Odocoileus virginianus), collared peccary (Dicotyles angulatus), coati (Nasua narica), but also a potential competitors such as puma (Puma concolor) and coyote (Canis latrans).

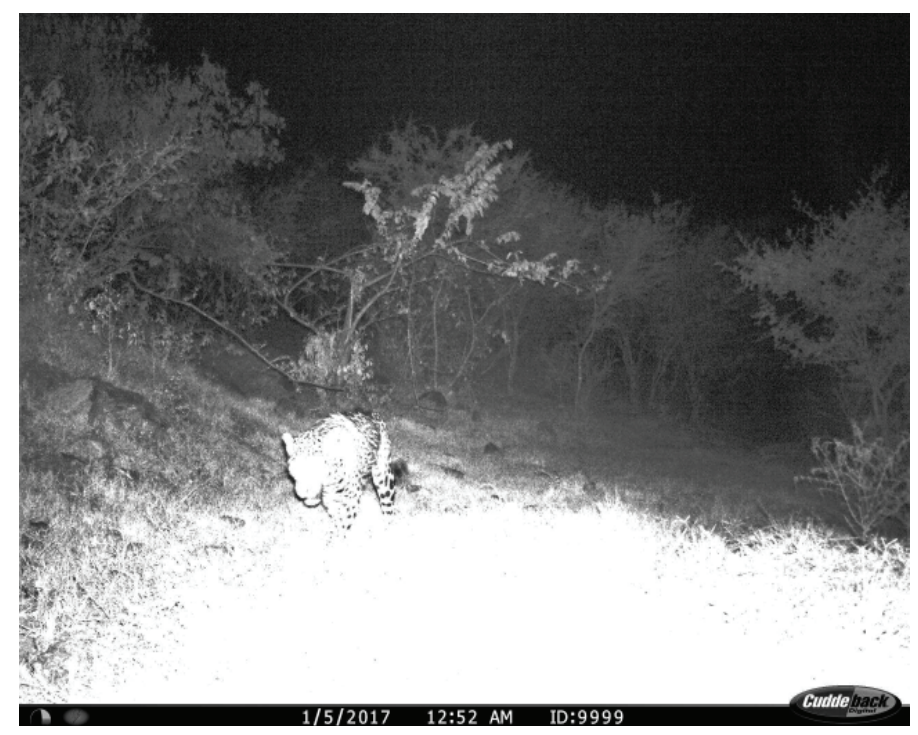

Figure 2. First photographic record of a jaguar (Panthera onca) in the Tepalcatepec basin, municipality of Tocumbo, Michoacán, México.

\section{Discussion}

This new record modifies the perception concerning which region constitute the most likely contact area between northern and central jaguar populations (Jalisco-Michoacán). Previous hypothesis considered the Michoacán coast as the potential contact region based on the location of old anecdotal reports proposed by Sanderson et al. 2002 and Nuñez $(2012$, 2011). However, no photographic evidence has been obtained for that region during the last 30 years even though substantial survey effort was allocated (Núñez 2007), therefore such hypothesis should be rejected until updated evidence is provided (Figure 1).

The Tepalcatepec river basin constitute now the most likely area of contact and mobility for the jaguar between Michoacán and Jalisco as previously assumed (CharreMedellín et al. 2014b). Additional supporting evidence comes from the characteristics of the areas with actual jaguar activity in Michoacán. The area where the species present a small but resident population is a rugged mountain range of Arteaga (Sierra Madre del Sur), where canyons and ravines seem to provide cover for the jaguar. Moreover, the second region with jaguar presence is rugged terrain along the higher Balsas basin (Churumuco municipality). Rugged terrain and low human density seem to be the factors found in common for all the areas where jaguar is present in Michoacán (Charre-Medellín et al. 2013; Charre-Medellín et al. 2014b). Future survey efforts should intensify for the Jalmich Sierra region to determine the jaguar frequency of activity. A buffer area free from land use changes should be designated considering the location of the jaguar record and forest cover in Tepalcatepec river Basin. Restoration programs should initiate to consolidate the long term preservation of the cultural and natural heritage of the region. The Sierra Jalmich constitute now a priority area for jaguar conservation in México, and the official inclusion in national conservation initiatives should be recognized officially. The jaguar site should be combined with nearby localities such as the Ecological Preservation Area of Chorros del Varal, to design a network of wildlife refuge areas connected by corridors, as other endangered species such as military macaws (Ara militaris), margay (Leopardus wiedii), ocelot (Leopardus pardalis), and otter (Lontra longicaudis) have been registered in the region (Charre-Medellín et al. 2014a).

The surveys for presence, activity and abundance for jaguar should be expanded in this area, including neighboring localities in Jalisco state. An analysis of the primary vegetation actual cover in the region is urgent, and potential routes connecting the distinct jaguar populations among the Sierra Madre del Sur, the Bajo Balsas and the Tepalcatepec basin should be designed and evaluated. Official programs (payment for environmental services) should allocate economic support to land owners. Cattle ranchers must be compensated also if livestock loses caused by predation of wild carnivores occur in areas that are considered of greater value for the jaguar conservation. 


\section{Acknowledgments}

We would like to thank the Colegio de Michoacan, who initiated conservation efforts for wildlife in this zone. We appreciate the interest, active participation and assistance from the communities of Palo Bobo, Desmontes, Rodeo and El Santuario. We would like to thank the Coordination for Scientific Research at UMSNH for partially funding this research and CONACYT for a fellowship studies fund provided for JFCM (239248). We appreciate the field support given by students of the Laboratory of Priority Terrestrial Vertebrates and the Faculty of Biology of the Universidad Michoacana de San Nicolás de Hidalgo (UMSNH) for their facilities for the preparation of the manuscript.

\section{Literature cited}

Barragán, E., J. Ortiz, and A. Toledo. 2007. Patrimonios. Cuenca del Río Tepalcatepec. El Colegio de Michoacán /Gobierno del Estado de Michoacán. Michoacán, México.

Botello, F., Villaseñor E., Aranda M., G. Magaña-Cota, and L. Guevara. 2011. Guía de Campo para el Monitoreo Participativo de Vertebrados Utilizando Rastros y Fototrampeo. Reserva de la Biósfera de Tehuacán-Cuicatlán, Oaxaca, México. Conservación Biológica y Desarrollo Social, A. C. Ciudad de México, México.

Caso A., López-González, C., E. Payan, E. EiziriK, T. de Oliveira, R. LeitePitman, M, Kelly, and C. Valderrama. 2008. Panthera onca. The IUCN Red List of Threatened Species., 2008. In: IUCN Red List of Threatened Species 2008. Available at: http://dx.doi. org/10.2305/IUCN.UK.2008.RLTS.T15953A5327466.en

Ceballos, G., H. Zarza, C. Chávez, and J. F. González-Maya. 2016. Ecology and conservation of jaguars in México: State of knowledge and future challenges. Pp. 273-289, in Tropical Conservation: Perspectives and local and global priorities (Aguirre A., and R. Sukumar, eds.). Oxford University Press. Oxford, U. S. A.

Charre-Medellín, J., T. Monterrubio-Rico, M. Álvarez-Jara, and C. Colín-Soto. 2014a. Riqueza de mamíferos de una barranca tropical aislada en Michoacán, México. Mammalogy notes $1: 18-21$.

Charre-Medellín, J. F., T. C. Monterrubio-Rico, F. J. Botello, L. LeÓn-Paniagua, L., AND R. Núñez. 2013. First records of jaguar (Panthera onca) from the state of Michoacán, México. The Southwestern Naturalist 58:264-268.

Charre-Medellín, J., T. Monterrubio-Rico, and D. Guido-Lemus. 2014b. Nuevo registro de jaguar (Panthera onca), en el centro occidente de México. Revista Mexicana de Biodiversidad 85:1295-1299.

Comisión Nacional de Áreas Naturales Protegidas (CONANP). 2009. Programa de Acción para la Conservación de la Especie. Jaguar (Panthera onca). Secretaría de Medio Ambiente y Recursos Naturales, Comisión Nacional de Áreas Protegidas. Ciudad de México, México.

De la Torre, J. A., J. F. González-Maya, H. Zarza, G. Ceballos, and R. A. Medelíín. 2018. The jaguar's spots are darker than they appear assessing the global conservation status of the jaguar Panthera onca. Oryx 52:300-315.
Instituto Nacional de Estadística Geografía e Informática (INEGI). 2010. Conjunto Nacional de Uso de Suelo y Vegetación, a escala 1:250,000, Serie IV. México.

Mendoza, M., A. Toledo, A. Velázquez, H. Plascencia, and V. Garduño. 2009. La cuenca del Río Tepalcatepec. P. 53, in Atlas fisicogeográfico de la cuenca del Tepalcatepec (Mendoza, M., A. Velázquez, A. Larrazábal, and A. Toledo, eds.). Secretaria de Medio Ambiente y Recursos Naturales, Instituto de Ecología, Centro de Investigaciones en Geografía Ambiental, Universidad Nacional Autónoma de México, El Colegio de Michoacán. Michoacán, México.

Monroy-Vilchis, O., O. Sanchez, U. Aguilera-Reyes, P. Suarez, and V. URIOS. 2008. Jaguar (Panthera onca) in the State of México. The Southwestern Naturalist 53:533-537.

NúÑEZ, R. 2011. A jaguar corridor in Western México. Wild Felid Monitor 4:20

NúNEEZ, R. 2007. Distribución y situación del jaguar en el occidente de México. Pp. 25-40, in Conservación y manejo del jaguar en México: estudios de caso y perspectivas (Ceballos, G., C. Chávez, R. List, and H. Zarza, eds.). CONABIO-Alianza WWF/Telcel-Universidad Nacional Autónoma de México. Ciudad de México, México.

NúÑEZ, R. 2012. The status of jaguars in Michoacán, México. Wild Felid Monitor 5:18.

Rabinowitz, A., AND K. Zeller. 2010. A range-wide model of landscape connectivity and conservation for the jaguar, Panthera onca. Biology Conservation 143:939-945.

Rodríguez-Soto, C., O. Monroy-Vilchis, L. Maiorano, L. Boitani, J. C., Faller, M. A. Briones, R. Núñez, O. Rosas-Rosas, G. Ceballos, and A. FALCUCCI. 2011. Predicting potential distribution of the jaguar (Panthera onca) in México: identification of priority areas for conservation. Diversity and Distributions 17:350-361.

Sanderson, E. W., K. H. Redford, C. L. B. Chetkiewicz, R. A. Medellin, A. Rabinowitz, J. G. Robinson, and A. B. Taber. 2002. Planning to save a species: the jaguar as a model. Conservation Biology 16:58-72.

Secretaría de Medio Ambiente y Recursos Naturales (SEMARNAT). 2010. Norma Oficial Mexicana NOM-059-SEMANRNAT-2010. Protección Ambiental -Especies nativas de México de flora y fauna silvestres-Categorías de riesgo y especificaciones para su inclusión, exclusión o cambio. Lista de especies en riesgo. Ciudad de México, México.

Associated editor: Monica Díaz

Submitted: November 1, 2017; Reviewed: November 24, 2017;

Accepted:May 22, 2018; Published on line:May26, 2018. 